\title{
Cloning, expression and sequence diversity of iss gene from avian pathogenic Escherichia coli (APEC) isolated in Brazil
}

\author{
Clonagem, expressão e diversidade na seqüência do gene iss de \\ Escherichia coli patogênica para aves (APEC), isolada no Brasil
}

\author{
Ana Angelita Sampaio Baptista ${ }^{1}$; Renata Katsuko Takayama Kobayashi²; \\ Emerson José Venâncio ${ }^{3}$; Marilda Carlos Vidotto ${ }^{4 *}$
}

\begin{abstract}
The Iss (Increased serum survival) protein is an important characteristic of resistance to complement system of avian pathogenic Escherichia coli (APEC). The objectives of this work were to cloning and verify the sequence diversity of iss gene from APEC and characterize the recombinant Iss protein. The iss gene of 309 bp was amplified by PCR, cloned and expressed in E. coli BL21 (DE3) using the pET SUMO vector. The iss gene from APEC9 strain was classified as iss type 1 by differentiation of the three iss gene allele types. The protein was expressed by induction of IPTG and purified in resin charged with the nickel ion. Antibodies IgY anti rIss reacted with rIss showing a molecular mass of $22 \mathrm{kDa}$, corresponding $11 \mathrm{KDa}$ of Iss protein and $11 \mathrm{KDa}$ SUMO protein.
\end{abstract}

Key words: Avian pathogenic E. coli (APEC), gene iss, cloning, RIss, serum resistance

\section{Resumo}

A proteína Iss (increased serum survival) é uma importante característica de resistência ao sistema complemento da Escherichia coli patogênica para aves (APEC). Os objetivos deste trabalho foram clonar e verificar a diversidade da seqüência do gene iss de APEC e caracterizar a proteína Iss recombinante. $\mathrm{O}$ gene iss de $309 \mathrm{bp}$ foi amplificado por PCR, clonado e expresso na E. coli BL21 (DE3) utilizando o vetor pET SUMO. O gene iss da APEC9 foi classificado como iss tipo 1 pela diferenciação entre 3 tipos de iss alelos. A proteína Iss foi expressa pela indução com IPTG, purificada em coluna com resina ligada ao íon níquel e utilizada na imunização de galinhas poedeiras. Anticorpos da classe IgY anti rIss reagiram com a proteina rIss, a qual apresentou massa molecular de $22 \mathrm{kDa}$, correspondendo $11 \mathrm{kDa}$ da Iss e $11 \mathrm{kDa}$ da proteína SUMO.

Palavras-chave: Escherichia coli patogênica para aves (APEC), gene iss, clonagem, riss, resistência sérica

\footnotetext{
${ }^{1}$ Mestranda do Programa de Pós-Graduação em Ciência Animal, Centro de Ciências Agrárias, Universidade Estadual de Londrina. E-mail: angelita_sampaio@yahoo.com.br

${ }^{2}$ Profa. Dra. do Depto. de Microbiologia, Centro de Ciências Biológicas, Universidade Estadual de Londrina. E-mail:kobayashirkt@, uel.br

${ }_{3}^{3}$ Depto. de Ciências Patológicas, Centro de Ciências Biológicas, Universidade Estadual de Londrina. E-mail: emersonj@uel.br

${ }^{4}$ Profa. Sênior do Depto de Medicina Veterinária Preventiva, Centro de Ciências Agrárias, Universidade Estadual de Londrina, Campus Universitário, Caixa Postal 6001. Cep 86055-900, Londrina, PR. E-mail: macarlos@uel.br

* Autor para correspondência
} 


\section{Introduction}

Escherichia coli strains designated as avian pathogenic E. coli (APEC) possess specific virulence factors and are able to cause avian colibacillosis (VIDOTTO et al., 1990; DHOMOULIN; FAIRBROTHER, 1999). This disease is a serious problem for the poultry industry, since it causes high economic losses. The most severe manifestation of avian colibacillosis is septicemia, which is characterized by air sacculitis, pericarditis, perihepatitis, and salpingitis (GROSS, 1994).

Several potential virulence genes were identified in APEC, and their virulence-associated bacterial properties include adherence to the respiratory tract, resistance to the immunological defences, multiplication under iron-restricted conditions, and production of cytotoxic effects (DELICATO et al., 2003; DHO-MOULIN, FAIRBROTHER, 1999; VANDEKERCHOVE et al., 2005). The genes more frequently found in pathogenic isolates and not detected in faecal isolates from healthy birds are $t s h$, iutA, iss, $c v a \mathrm{C}$, papC, which were found in different associations among several putative pathotypes (DELICATO et al., 2003; LARAGIONE, WOODWARD, 2002; RODRIGUEZ-SIEK et al., 2005a, 2005b).

Recently we cloned and characterized the $t s h$ and iutA genes from APEC. The anti-Tsh inhibited the hemagglutinating activity of strains APEC13 and BL21/pET101-tsh. Anti-IutA IgY was able to inhibit the IutA biological activity, inhibiting the sensitivity to cloacin DF13 of APEC9 (SIMÕES et al., 2006; TOKANO et al., 2008). However, antiIutA IgY did not inhibit the growth of APEC9 in M9 and did not protect chickens inoculated with APEC, suggesting that APEC possess another iron acquisition mechanism distinct of aerobactin (TOKANO et al., 2008).

Published research has shown that the increased serum survival gene (iss) is strongly correlated with an APEC isolate's ability to cause disease in poultry (RODRIGUEZ-SIEK et al., 2005; LYNNE et al.,
2007) and has been localized to large plasmids that typify the APEC pathotype (GIDDINGS et al., 2002; JOHNSON; JOHNSON, NOLAN, 2006). Serum resistance in E. coli has been related to several structural factors including a K1 antigenic capsule (LEYING et al., 1990) and certain outer membrane proteins, including TraT, Iss, and OmpA (BINNS, MAYDEN; LEVINE, 1982; CHUBA; PALCHAUDHURI; LEON, 1986; WEISER, GOTSCHLICH, 1991).

The protein Iss product of iss, is thought to occur as a 10 to $11 \mathrm{kD}$ lipoprotein in the bacterial outer membrane (HORNE et al., 2000) and presents 90\% similarity with the Bor protein, a lipoprotein of the cell envelope of $E$. coli lambda lysogens (LYNNE et al., 2007).

Recently, an alignment of all of iss and bor sequences revealed three genetically distinct alleles of iss, which have been designated iss types 1 to 3 and can discriminate the $E$. coli pathotypes (JOHNSON; WANNEMUEHLER; NOLAN, 2008).

The objective of this study was cloning, sequencing and expression of the iss gene from APEC isolated in Brazil, and in silico comparative sequence analysis of iss from our Brazilian APEC vs. other iss sequences in GenBank.

\section{Materials and Methods}

\section{Bacterial strain}

The avian pathogenic Escherichia coli strain APEC9 used in this study was recovered from the trachea of a colisepticemic chicken in the Parana State-Brazil (VIDOTTO et al., 1990). This strain shows resistance to tetracycline, ampicillin and serum complement. It is produces colicin V, and has an iron uptake system mediated by aerobactin and carries one large plasmid of approximately 120 kilobases (Kb) (VIDOTTO et al., 1990). The APEC9 strain presented serotype O2:H9:K1 (MOURA; IRINO; VIDOTTO, 2001) and was pathogenic to 1-day-old chickens by means of pathogenicity test, 
presenting $\mathrm{LD}_{50}$ of $1 \times 10^{5}$ cells/ $\mathrm{ml}$. The iutA, tsh, iss, pap $\mathrm{C}$, pap $\mathrm{G}$ and $c v a \mathrm{C}$ genes were detected in the E. coli APEC9 strain (DELICATO et al., 2002; DELICATO et al., 2003).

\section{Cloning and sequence analysis of the iss gene}

The entire iss open reading frame was amplified from APEC9 genomic DNA by PCR. A pair of primers was constructed according to sequences in GenBank, iss forward 5' ATGATGCAGGATAATAAGATGAAAAAAATG - 3' and iss reverse- 5'CTATTGTGAGCAATATACCCGG - 3'. PCR was carried out in a total volume of $50 \mu \mathrm{l}$ containing $50 \mathrm{ng}$ of DNA template, $1 \mu \mathrm{l}$ each of the primers at $20 \mathrm{pmol}$, and $200 \mu \mathrm{M}$ of each deoxynucleoside triphosphate, 2U Taq DNA polymerase (Invitrogen Life Technologies, São Paulo, Brazil). The PCR conditions were as follows: $94^{\circ} \mathrm{C}$ for 5 min followed by 30 cycles of $94^{\circ} \mathrm{C}$ for $1 \mathrm{~min}$, annealing at $50^{\circ} \mathrm{C}$ for $1 \mathrm{~min}$, and $72^{\circ} \mathrm{C}$ for $1 \mathrm{~min}$, followed by a final extension at $72^{\circ} \mathrm{C}$ for $7 \mathrm{~min}$ in a thermal cycler (mastercycler personal eppendorf $®$ ). The amplified DNA was visualized in $1.0 \%$ agarose gels stained with ethidium bromide.

PCR product was quantified and $50 \mathrm{ng}$ were used as insert in the pET SUMO ${ }^{\circledR}$ vector $(5.5 \mathrm{~Kb})$ (Invitrogen, Carlsbad, CA, USA). Chemically competent $E$. coli host strain Mach cells (Invitrogen) were then transformed with $3 \mu$ of the cloning reaction. The transformants colonies were selected on plates containing $30 \mu \mathrm{g}$ of kanamicin, and the recombinants plasmids were extracted by alkaline lysis (SAMBROOK; FRITSCH; MANIATIS, 1990). The presence of iss genes were confirmed by PCR and subsequent restriction enzyme digestion of recombinant plasmids with EcoRI and SmaI. The correct position of iss gene was confirmed by sequencing with primers SUMO forward (5'AGATTCTTGTACGACGGTATTAG-3') T7 reverse (5'-TAGTTATTGCTGAGCGGTGG-3') and iss primers, utilizing commercial kit BigDye Terminator (Applied Biosystems, CA, USA).

The obtained sequences were analyzed by BLAST through the NCBI website (http://www.ncbi.nlm. nih.gov/) to verify the sequence identity. DNA and amino acid sequence analyses were carried out by the software "CAP3 Contig Assembly Program" and "Clustal W (1.81) Multiple Sequence Alignments" and "Six Frame Translation of Sequence" (LARKIN et al., 2007).

\section{Expression of genes on E. coli strain and purification of recombinants Iss proteins.}

The recombinant plasmids were utilized in transformation reactions with $E$. coli BL21 Star (DE3) One Shot (Invitrogen Life Technologies, Sao Paulo, Brazil). The BL21/pET SUMO-iss strain was grown to an optical density of $\mathrm{OD}_{600 \mathrm{~nm}}$ 0.5 , and IPTG (Invitrogen Life Technologies, São Paulo, Brazil) was added to $1 \mathrm{mM}$ and aliquots were removed at different times to choose the best time for expression. The cells were collected by centrifugation and treated with the buffer containing $6 \mathrm{M}$ guanidine- $\mathrm{HCl}$ and sonicated on the ice with three 5-second pulses at the high intensity. The lysate was then centrifuged at $3000 \mathrm{x}$ g for $15 \mathrm{~min}$ and the supernatant was transferred to Ni-NTA resin (Qiagen, Sao Paulo, Brazil); previously washed with the Denaturing Binding Buffer ( $8 \mathrm{M}$ urea, $100 \mathrm{mM}$ $\mathrm{NaH}_{2} \mathrm{PO}_{4}, 10 \mathrm{mM}$ Tris-Cl, $\mathrm{pH}$ 8.0). The supernatant and resin were incubated for $1 \mathrm{~h}$ on a rotation wheel. Then the resin was washed once with the Denaturing Binding Buffer at $\mathrm{pH} 8.0$, twice with the buffer at $\mathrm{pH}$ 6.3, and three times with the buffer at $\mathrm{pH} 5.9$. The protein was eluted using $8 \mathrm{M}$ urea buffer at $\mathrm{pH}$ 4.0. The protein concentration was measured using the Bradford method (1976) and analyzed on SDSPAGE $15 \%$. 
Production of $\operatorname{Ig} Y$ and hyperimmune serum in hens

The procedures used were approved by the Ethics Committee for Experiments in Animals (CEEA, $n^{\circ}$ 39/07), Universidade Estadual de Londrina. Two Shaver breed chickens were utilized for the production of IgY anti-rIss. Each animal received three inoculations of $100 \mu \mathrm{g}$ (LARSSON; CARLANDER; WILHELMSSON, 1998) of protein at intervals of 14 days by the intramuscular via. During the first inoculation the complete Freund adjuvant (Sigma Immuno Chemicals, São Paulo, Brazil) was used, while the incomplete Freund adjuvant was administered in all other inoculations. The eggs were collected daily, beginning one week before immunization until two weeks after the last inoculation. The IgY extraction was realized as described Akita and Nakai (1993). The IgY purifity was then centrifuged, the obtained sediment resuspended in sterile water dialysed and maintained at $-20{ }^{\circ} \mathrm{C}$ until usage.

Extractions of post-immunization $\operatorname{IgY}$ were adsorbed with E. coli BL21 Star for use in Western blot.

\section{SDS PAGE and Western blot}

The expression and the localization of recombinant Iss was demonstrated by SDS-PAGE and Western blot. Purified recombinant proteins were loaded in a $15 \%$ SDS-PAGE gel. The gel were either stained with Comassie Brilhant blue or transfer to a nitrocellulose membrane (Amersham International, Amersham, UK) for Western blotting analysis (TOWBIN; GORDON, 1984). The membrane was blocked with 5\% skim milk for 1 $\mathrm{h}$ at room temperature, washed in PBS-T (PBS + $0.1 \%$ Tween 20 ), and incubated for $1 \mathrm{~h}$ with a 1:500 dilution of anti-rIss. The membrane were then incubated with chicken anti-IgY $(1: 10,000)$ stained with peroxidase (Sigma). The membrane was washed and the rIss were detected by means of the enhanced chemiluminescence (ECL) Western Blotting System (Amersham International, Amersham, UK). Protein molecular mass markers were used as standards.

\section{Results}

The insertion of the iss gene of APEC9 into the plasmids pETSUMO/iss was confirmed. The recombined plasmid pETSUMO/iss, which was cleaved with the enzyme EcoRI, presented molecular mass of $5.8 \mathrm{~Kb}, 5.5 \mathrm{~Kb}$ of the vector and $0.3 \mathrm{~Kb}$ of the iss gene. The iss gene was amplified using the $\mathrm{pETSUMO} /$ iss plasmids, and the sequence of the iss gene showed that it was inserted at the correct positions into the vector.

The complete iss sequence from APEC9 was deposited in GenBank (Accession № FJ824853). The Figure 1 shows the alignment of the iss sequence from APEC9 with the sequence of three genetically distinct alleles of iss, designated iss types 1 to 3 and with the bor sequence, demonstrating that APEC 9 has the iss gene type 1 . There was $100 \%$ of similarity among the iss sequence from APEC9 with those of others APEC strains isolated of different countries and different serotypes; from USA O1:K1 (DQ381420), O2 (AF042279, AY545598), O78:K80 (AF449498), O103 (CP001232); from Australia O non-typeable:H28 (EU330199); from Iran O78 (FJ416147) and from China O1 (DQ295188), O2 (DQ295187), O78 (DQ309288, DQ309289, DQ309290, O109 ( DQ309281, DQ309291), O119 (DQ309292). Also, this sequence type 1 was found in chicken fecal strain O5 from China (DQ299279, DQ29980, DQ299399, DQ299400). 
IssAPEC9ATGCAGGATAATAAGATGAAAAAAATGTTATTTTCTGCCGCTCTGGCAATGCTTATTAC

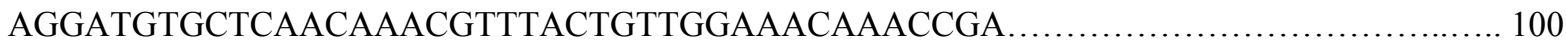

Iss type 1 100

Iss type2 G.

G. 100

Iss type 3

G.

G.

T. 100

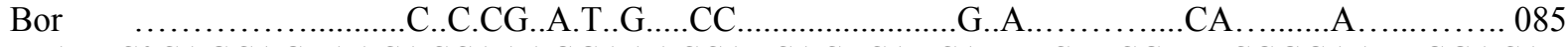

IssAPEC9CAGCAGTAACACCAAAGGAAACCATCACTCATCATTTCTTCGTTTCGGGAATTGGACA

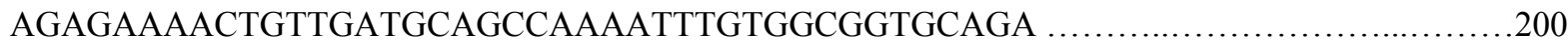

Iss type 1

Iss type 2

Iss type 3

Bor

C......

G...

C

C..........................GA.

.

200

Iss APEC9

...

T........G..GA

C........T

A

.200

IssAPEC9AAATGTTGTTAAAACAGAAACTCAGCAAACATTCGTAAATGGATTGCTCGGTTTTATC

ACTTTTGGCATCTATACTCCGCTGGAAGCCCGGGTATATTGC ................................. 300

Iss type 1

Iss type2

Iss type 3

.C...

T...........T.

300

Bor

C

T...........T.

.G..T..G

300

Iss APEC9 TCACAATAG. 309

Iss type 1

309

Iss type 2

A 309

Iss type 3

A 309

Bor....A.

A 294

Figure 1. Alingment of iss gene of APEC 9 strain from Parana State-Brazil and iss type 1, 2, 3, and bor genes sequences, indicating the nucleotides that are different from APEC 9 and type 1 sequences.

The Fig. 2A shows the rIss protein, an expected band around $22 \mathrm{kDa}$, corresponding $11 \mathrm{kDa}$ of Iss and $11 \mathrm{kDa}$ of SUMO protein, which was more evident after $4 \mathrm{~h}$ of induction with IPTG (lane 3). This band was observed in the insoluble fraction or inclusion bodies and was absent in the negative control. rIss was solubilized and purified with the Ni-NTA purification system under denaturing conditions. The results obtained from SDS-PAGE showed that rIss was successfully expressed in BL21 (DE3) and purified by means of Ni-NTA resin (Fig.2 A, lane 4), although the SUMO-Iss was not cleaved with SUMO protease at different conditions as manufacturer's recommendations.

The expression of rIss protein and its reactivity with the hen hyper-immune serum by Western blotting are shown in Figure 2 B. 

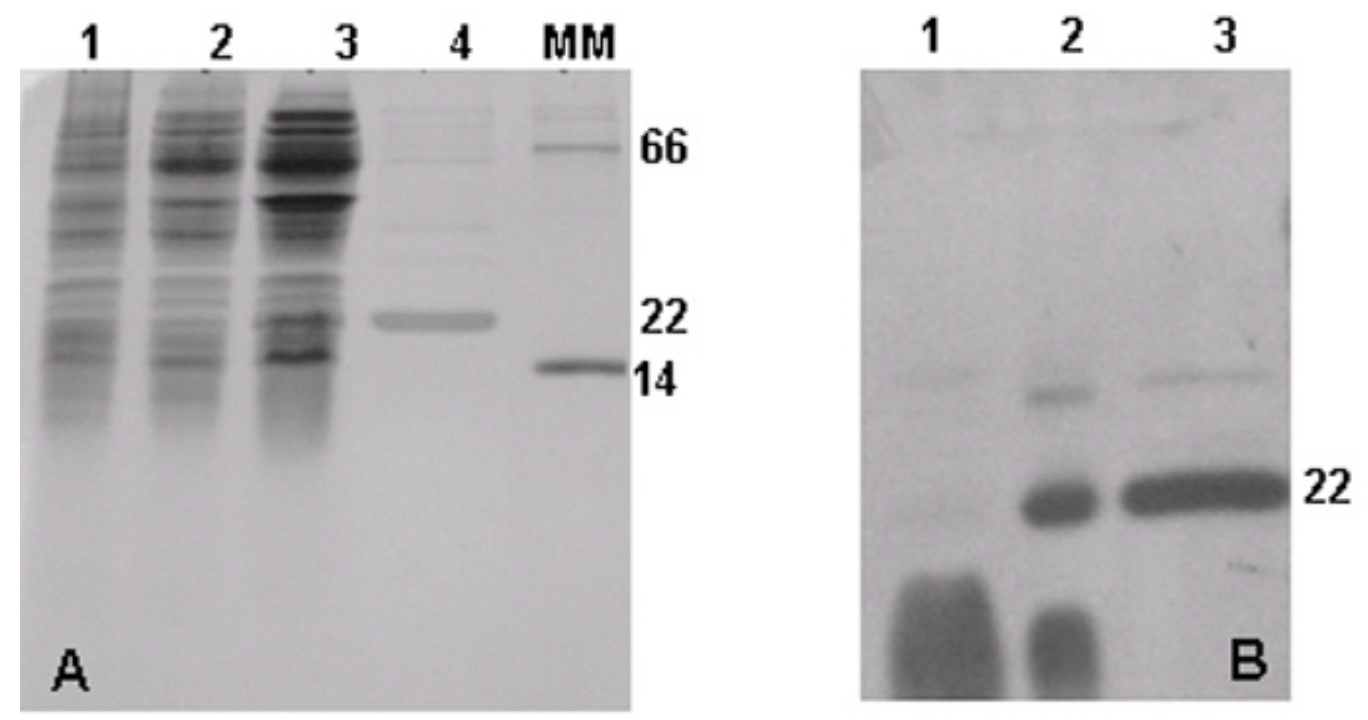

Figure 2. Expression of the rIss protein by clone E. coli/pETSUMO-iss and immunological response of this protein in chickens. (A) SDS-PAGE 15\% stained with Comassie brilhant blue. Lane 1- E. coli BL21; lane 2-BL21/pETSUMOiss non induced; lane 3-BL21/pETSUMO-iss induced with IPTG 1mM; lane 4 - eluted rIss; lane 5 - Mass Molecular. The band of approximately $22 \mathrm{kDa}$ correspond to recombinant Iss protein. (B) Western blot with anti-rIss IgY and anti-chicken IgG conjugated with peroxidase. Lane $1-E$. coli BL21; lane 2 - clone BL21/pETSUMO-iss induced with IPTG $1 \mathrm{mM}$; lane 3 - eluted rIss.

\section{Discussion}

APEC has been widely studied for its role as agent extraintestinal infections, which causes high losses in the poultry industry (MINHARRO et al., 2001; ASSIS et al., 2003; BARNES, GROSS, 1997). An important gene responsible by serum resistance presented by APEC is the iss gene (BINNS; MAYDEN; LEVINE, 1979; LYNNE et al., 2007).

Recently, the differentiation of the three iss gene allele types in E. coli provides an additional tool for discriminating among E. coli pathotypes (JOHNSON; WANNEMUEHLER; NOLAN, 2008). The plasmid-borne iss allele (designated type 1) was highly prevalent among APEC (78\%) and neonatal meningitis-associated E. coli isolates (66\%) but not among uropathogenic E. coli isolates. The types 2 and 3 was highest among necrotoxigenic and human ExPEC strains, respectively (JOHNSON; WANNEMUEHLER; NOLAN, 2008). The different iss types appear to have evolved from a bor-containing phage precursor, with several key events leading to the current iss alleles present on different prophage elements and conjugative plasmids (JOHNSON; WANNEMUEHLER; NOLAN, 2008).

In this work, we sequenced the iss sequence from APEC9 (O2:H9:K1) and the alignment this sequence with those described in the GeneBank showed that it belong to iss type 1 (Fig.1). This sequence has $100 \%$ of similarities with those of different serotypes APEC strains from of USA, Australia, Iran and China. In China the sequence type 1 was found in $E$. coli $\mathrm{O} 5$ strain isolated from chicken fecal, however we found E. coli O5 as APEC in Brazil (MOURA; IRINO; VIDOTTO, 2001).

The iss type 1, as well as others genes associated with the virulence of APEC, is commonly plasmidlinked (JOHNSON et al., 2002; JOHNSON; JOHNSON; NOLAN, 2006; RODRIGUEZ-SIEK et al., 2005a, 2005b, Skyberg et al., 2006) and the APEC plasmids may serve as reservoirs of resistance or virulence genes for human ExPEC. Thus, APEC could be a possible source of UPEC causing UTIs or other diseases in human beings 
(EWERS et al., 2007; JOHNSON et al., 2007; RAMCHANDANI et al., 2005; RODRIGUEZSIEK et al., 2005a). Several plasmid-linked APECderived sequences (tsh, $c v a \mathrm{~B}$, tra $\mathrm{R}$, traC and $\operatorname{sop} \mathrm{B}$ ) were predominantly present in APEC, as compared to UPEC (KARIYAWASAM; SCACCIANOCE; NOLAN, 2007), however the iss gene of UPEC is commonly found in the chromosome and it is of the iss type 2 (JOHNSON; WANNEMUEHLER; NOLAN, 2008). In our analysis, the iss type 1 was found in only a plasmid of UPEC (AY205565).

Iss and Bor proteins are exposed on E. coli outer membrane where they may be recognized by the host's immune system (LYNNE et al., 2007). In this work, the iss gene was successfully cloned into pETSUMO and the recombinant protein SUMOIss was purified in Ni-NTA resin with denaturing conditions (Fig.2). Although SUMO, expressed by pETSUMO vector, increases the solubility of recombinant proteins, the results showed that rIss is insoluble. The SUMO-Iss was not cleaved with SUMO protease and the antibodies elicited by SUMO-Iss were directed against SUMO and not Iss. This response can be due the size of SUMOIss that is two times the size of Iss. Others authors also cloned the iss gene, but they used the pGEX$6 \mathrm{P}-3$ vector, and the purification of protein was by affinity chromatography with Glutatione-Sepharose (FOLEY et al., 2000; LYNNE; FOLEY; NOLAN, 2006). However, chicken immunize with GST-Iss were able to produce antibody against Iss (LYNNE; FOLEY; NOLAN, 2006).

In conclusion, the iss gene from APEC 9 strain is the genotype 1 that is highly prevalent among APEC, and the antibodies IgY anti recombinant Iss could be used in diagnostic protocols.

\section{Acknowledgments}

This work was supported by the "Conselho Nacional de Desenvolvimento Científico e Tecnológico" (CNPq).

\section{References}

AKITA, E. M.; NAKAI, S. Comparison of four purification methods for the production of immunoglobulins from eggs laid by hens immunized with an enterotoxigenic $E$. coli strain. Journal Immunological Methods, v. 160, p. 207-214, 1993

ASSIS, M. T. Q. M.; GRUBER, G. L.; HOFMEISTER, A. W.; GUIMARÃES, A. M. P. Avaliação do percentual de descarte na condenação parcial de frangos. Revista Nacional da Carne, v. 313, p. 22-31, 2003.

BARNES, J. H.; GROSS, W. B. Colibacillosis. In: CALNEK, B. W.; BARNES, H. J., BEARD, C. W.; MCDOUGALD, L. R.; SAIF, Y. M. (Ed.). Diseases of poultry. 10th ed. Ames, IA, USA: Iowa State University Press, p. 131-139. 1997.

BRADFORD, M. M. A rapid and method for the quantification of microgram quantities of proteins utilizing the principe of protein. Analytical Biochemistry, v. 72, p. 248-254, 1976.

BINNS, M. M.; MAYDEN, J.; LEVINE, R. P. Further characterization of complement resistance conferred on Escherichia coli by the plasmid genes traT of R100 and iss of ColV, I-K94. Infection and Immunity, v. 35, n. 2, p. 654-659, 1982.

CHUBA, P. J.; PALCHAUDHURI, S.; LEON, M. A. Contributions of traT and iss genes to the serum resistance phenotype of plasmid ColV2-K94. FEMS Microbiology Letters, v. 37, p. 135-140, 1986.

DELICATO, E. R.; BRITO, B. G.; GAZIRI, L. C. J.; VIDOTTO, M. C. Virulence associated genes in Escherichia coli isolates from poultry with colibacillosis. Veterinary Microbiology, v. 94, p. 97-103, 2003.

DELICATO, E. R.; BRITO, B. G.; KONOPATZKI, A. P.; GAZIRI, L. C. J.; VIDOTTO, M. C. Occurrence of the Temperature-Sensitive Hemagglutinin Among Avian Escherichia coli. Avian Diseases, v. 46, n. 3, p. 713-716, 2002.

DHO-MOULIN, M.; FAIRBROTHER, J. M. Avian pathogenic Escherichia coli APEC. Veterinary Research, v. 30, p. 299-313,1999.

EWERS, C.; LI, G.; WILKING, H.; KIEBLING, S.; ALT, K.; ANTÁO, E. M.; LATURNUS, C.; DIEHL, I.; GLODDE, S.; HOMEIER, T.; BÖHNKE, U.; STEINRÜCK, H.; PHILIPP, H. C.; WIELER, L. H. Avian pathogenic, uropathogenic, and newborn meningitiscausing Escherichia coli: How closely related are they? Int J Med Microbiol, v. 297, p. 163-176. 2007. 
FOLEY, S. L.; HORNE, S. M.; GIDDINGS, C. W.; ROBINSON, M.; NOLAN, L. K. Iss from a virulent Escherichia coli. Avian Diseases, v. 44, p. 185-191, 2000.

GIDDINGS, C. W.; HORNE, S. M.; GIBBS, P. S.; WOOLEY, R. E.; SKYBERG, J.; OLAH, P.; KERCHER, R.; SHERWOOD, J. S.; FOLEY, S. L.; NOLAN, L. K. Location of increased serum survival gene and selected virulence traits on a conjugative $\mathrm{R}$ plasmid in an avian Escherichia coli isolate. Avian Diseases, v. 46, p. 342352, 2002.

GROSS, W. B. Diseases due to Escherichia coli in poultry, In: GYLES, C. L. E. coli in domestic animals and man. Wallingford, UK: CAB International, 1994. p. 237-259.

HORNE, S. M.; MCDONOUGH, J. P.; GIDDINGS, C. W.; NOLAN, L. K. Cloning and sequencing of iss gene from virulent avian Escherichia coli. Avian Diseases, v. 44, p. 179-184, 2000.

JOHNSON, T. J.; GIDDINGS, C. W.; HORNE, S. M.; GIBBS, P. S.; WOOLEY, R. E.; SKYBERG, J.; OLAH, P.; KERCHER, R.; SHERWOOD, J. S.; FOLEY, S. L.; NOLAN, L. K. Location of increased serum survival gene and selected virulence traits on a conjugative R plasmid in an avian Escherichia coli isolate. Avian Diseases, v. 46, p. 342-352, 2002.

JOHNSON, T. J.; JOHNSON, S. J.; NOLAN, L. K. Complete DNA sequence of a ColBM plasmid from avian pathogenic Escherichia coli suggests that it evolved from closely related colv virulence plasmids. Journal of Bacteriology, v. 188, n. 16, p. 5975-5983, 2006.

JOHNSON, T. J.; KARIYAWASAM, S.; WANNEMUEHLER, Y.; MANGIAMELE, P.; JOHNSON, S. J.; DOETKOTT, C.; SKYBERG, J. A.; LYNNE, A. M.; JOHNSON, J. R.; NOLAN, L. K. The genome sequence of avian pathogenic Escherichia coli strain $\mathrm{O} 1: \mathrm{K} 1: \mathrm{H} 7$ shares strong similarities with human extraintestinal pathogenic E. coli genomes. Journal of Bacteriology, v. 189, p. 3228-3236, 2007.

JOHNSON, T. J.; WANNEMUEHLER, Y. M.; NOLAN, L. K. Evolution of the iss Gene in Escherichia coli. Applied and Environmental Microbiology, v. 74, n. 8, p. 2360-2369, 2008.

KARIYAWASAM, S.; SCACCIANOCE, J.A.; NOLAN, L. K. Common and specific genomic sequences of avian and human extraintestinal pathogenic Escherichia coli as determined by genomic subtractive hybridization. $B M C$ Microbiology, v. 7, p. 81, 2007.
LARSSON, A.; CARLANDER, D.; WILHELMSSON, M. Antibody response in laying hens with small amounts of antigen. Food Agr Immunology, v. 10, p. 29-36, 1998.

LA RAGIONE, R. M.; WOODWARD, M. J. Virulence factors of Escherichia coli serotypes associated with avian colisepticaemia-review article. Research in Veterinary Science, v. 73, p. 27-35, 2002.

LARKIN, M. A.; BLACKSHIELDS, G.; BROWN, N. P.; CHENNA, R.; MCGETTIGAN, P. A.; MCWILLIAM, H.; VALENTIN, F.; WALLACE, I. M.; WILM, A.; LOPEZ, R.; THOMPSON, J. D.; GIBSON, T. J.; HIGGINS, D. G. Clustal W and clustal X version 2.0. Bioinformatics, v. 23, n. 21, p. 2947-2948, 2007.

LEYING, H.; SUERBAUM, S.; KROLL, H. P.; STAHL; D.; OPFERKUCH, W. The capsular polysaccharide is a major determinant of serum resistance in K-1-positive blood culture isolates of Escherichia coli. Infection and Immunology, v. 58, p. 222-227, 1990.

LYNNE, A. M.; FOLEY, S. L.; NOLAN, L. K. Immune response to recombinant Escherichia coli Iss protein in poultry. Avian Diseases, v. 50, p. 273-276, 2006.

LYNNE, A. M.; SKYBERG, J. A.; LOGUE, C. M.; NOLAN, L. K. Detection of Iss and Bor on the surface of Escherichia coli. Journal of Applied Microbiology, v. 102, p. 660-666, 2007.

MINHARRO, S.; LINHARES, G. F. C.; ANDRADE, M. A.; ROCHA, P. T.; SANTANA, A. P. Envolvimento de Escherichia coli, de Mycoplasma gallisepticum e de Mycoplasma synoviae em lesões de sacos aéreos em frangos abatidos no Estado de Goiás. Ciência Animal Brasileira, v. 2, n. 2, p. 111-117, 2001.

MOURA, A. C.; IRINO, K.; VIDOTTO, M. C. Genetic variability of avian Escherichia coli strains evaluated by enterobacterial repetitive intergenic consensus and repetitive extragenic palindromic polymerase chain reaction. Avian Diseases, v. 45, p. 73-81, 2001.

RAMCHANDANI, M.; MANGES, A. R.; DEBROY, C.; SMITH, S. P.; JOHNSON, J. R.; RILEY, L. W. Possible animal origin of human-associated, multidrug-resistant, uropathogenic Escherichia coli. Clinical Infection Disease, v. 40, p. 251-257, 2005.

RODRIGUEZ-SIEK, K. E.; GIDDINGS, C. W.; DOETKOTT, C.; JOHNSON, T. J.; NOLAN, L. K. Characterizing the APEC pathotype. Veterinary Reserch, v. 36, p. 241-256, 2005a.

RODRIGUEZ-SIEK, K. E.; GIDDINGS, C. W.; DOETKOTT, C.; JOHNSON, T. J.; FAKHR, M. K.; NOLAN, L. K. Comparison of Escherichia coli isolates 
implicated in human urinary tract infection and avian colibacillosis. Microbiology, v. 151, p. 2097-2110, $2005 b$.

SAMBROOK, J.; FRITSCH, E. F.; MANIATIS, T. Molecular cloning - a laboratory manual. New York: Cold Spring Harbor Laboratory Press, 1990. 3 v.

SIMÕES, R. C.; KOBAYASHI, R. K. T.; GAZIRI, L. C. J.; VIDOTTO, M. C. Cloning, sequencing, expression, and characterization of the tsh gene from an avian pathogenic Escherichia coli strain. Semina: Ciências Agrárias, Londrina, v. 27, n. 2, p. 253-260, 2006.

SKYBERG, J. A.; JOHNSON, T. J.; JOHNSON, J. R.; ClABOTS, C.; LOGUE, C. M.; NOLAN, L. K. Acquisition of avian pathogenic Escherichia coli Plasmids by a Commensal E. coli isolate enhances its abilities to kill chicken embryos, grow in human urine, and colonize the murine kidney. Infection and Immunity, v. 74, p. 6287-6292, 2006.

TOKANO, D. V.; KAWAICHI, M. E; VENÂNCIO, E. J.; VIDOTTO, M. C. Cloning and characterization of the iron uptake gene IutA from avian Escherichia coli. Brazilian Archives of Biology and Technology, v. 51, n.3, p. 473-482, 2008.
TOWBIN, H.; GORDON, J. Immunoblotting and dot immunobinding: current status and outlook. Journal Immunological Methods, v. 72, n. 2, p. 313-340, 1984.

VANDEKERCHOVE, D.; VANDEMAELE, F.; ADRIAENSEN, C.; ZALESKA, M.; HERNALSTEENS, J. P.; DEBAETS, L.; BUTAYE, P.; VAN IMMERSEEL, F.; WATTIAU, P.; LAEVENS, H.; MAST, J.; GODDEERIS, B.; PASMANS, F. Virulence-associated traits in avian Escherichia coli: comparison between isolates from colibacillosis-affected and clinically healthy layer flocks. Veterinary Microbiology, v. 108, p. 75-87, 2005.

VIDOTTO, M. C.; MULLER, E. E.; FREITAS, J. C.; ALFIERI, A. A.; GUIMARÃES, I. G.; SANTOS, D. S. Virulence factors of avian Escherichia coli. Avian Diseases, v. 4, p. 531-538, 1990.

WEISER, J. N.; GOTSCHLICH, E. C. Outer membrane protein A (OmpA) contributes to serum resistance and pathogenicity of Escherichia coli K-1. Infection and Immunology, v. 59, p. 2252-2258, 1991. 
